\title{
POVEZANOST AKADEMSKE PROKRASTINACIJE, AKADEMSKOG LOKUSA KONTROLE I OSOBINA LIČNOSTI S AKADEMSKIM USPJEHOM
}

\author{
Gabriela Galić \\ Hrvatsko katoličko sveučilište \\ Odjel psihologija, Ilica 242, 10000 Zagreb \\ gabriela.galic1911@gmail.com \\ Krunoslav Matešić \\ Hrvatsko katoličko sveučilište \\ Odjel psihologija, Ilica 242, 10000 Zagreb \\ krunoslav.matesic@unicath.hr \\ Ljiljana Pačić-Turk \\ Hrvatsko katoličko sveučilište \\ Odjel psihologija, Ilica 242, 10000 Zagreb \\ ljpturk@unicath.hr
}

\begin{abstract}
Sažetak
Cilj istraživanja bio je ispitati odnos akademske prokrastinacije, akademskog lokusa kontrole, osobina ličnosti te akademskog uspjeha kod studenata. Također se ispitivala povezanost akademske prokrastinacije i osobina ličnosti.

Varijable korištene u istraživanju objasnile su 20,1\% ukupne varijance akademskog uspjeha. Akademska prokrastinacija nije ostvarila značajnu prediktorsku ulogu u objašnjavanju akademskog uspjeha. Rezultati provedenog istraživanja pokazuju da je veći stupanj odgađanja akademskih obveza povezan s lošijim akademskim uspjehom, ali vrijedi i suprotno, što znači da studenti koji manje odgađaju akademske obveze postižu bolji uspjeh.

Osim toga, prema rezultatima značajni prediktori akademskog uspjeha su savjesnost i neuroticizam. Pokazalo se da je akademska prokrastinacija povezana s visokim rezultatima na neuroticizmu, a niskim rezultatima na savjesnosti. Internalni lokus kontrole pokazao se kao značajan prediktor akademskog uspjeha, što bi trebalo značiti da studenti s internalnim lokusom kontrole postižu bolji akademski uspjeh od studenata s eksternalnim lokusom kontrole.
\end{abstract}

Ključne riječi: akademska prokrastinacija, akademski uspjeh, osobine ličnosti, lokus kontrole 


\section{UVOD}

Većina ljudi se barem jedanput našla u situaciji u kojoj su odgađali obavljanje neke aktivnosti do trenutka neodgodivosti. Takvo ponašanje karakterizira sklonost traćenju dosta vremena prije nego što se započne s radom. Započinjanje rada sat vremena kasnije, od sljedećeg ponedjeljka ili prvog u mjesecu često se događa ljudima unatoč spoznaji da trebaju krenuti s radom odmah. Prokrastinacija je fenomen koji se intenzivno istražuje u posljednja dva desetljeća. Predstavlja zanimljivu temu istraživačima upravo zbog učestalosti pojavljivanja navedenog ponašanja $u$ različitim okolnostima.

Obrazovanje je jedno od područja u kojem se često spominje, jer se smatra da odgađanje doprinosi lošem uspjehu u obrazovanju. S obzirom na raširenost problematike, zanimanje javnosti za ovu tematiku raste, što se primjećuje kroz povećan broj literature i programa kojima se želi nadvladati ovaj oblik ponašanja.

Odgađanje dovodi studente do gomilanja obveza, manje vremena za njihovo kvalitetno izvršavanje te neizbježnu pojavu stresa. Na kraju to može rezultirati lošijim akademskim uspjehom i većim nezadovoljstvom samim sobom.

Postoji mnogo različitih definicija prokrastinacije, no većina njih definira taj pojam kao odgađanje ili zapostavljanje zadatka, cilja ili odluke (Gendron, 2011). U Hrvatskoj su relativno rijetka istraživanja koja se bave ovom tematikom pa se koriste različiti nazivi za opis takvog ponašanja, kao što su prokrastinacija, odugovlačenje ili odgađanje (Živčić-Bećirević, Smojver-Ažić i Martinac Dorčić, 2015).

Kroz veći broj istraživanja određene su različite vrste prokrastinacije, a jedna od važnijih je akademska prokrastinacija. Tipična ponašanja za akademsko odugovlačenje mogu biti: odgađanje trenutka kada osoba namjerava učiti, odgađanje trenutka kada učenje stvarno započne te nesklad između namjere učenja i stvarnog ponašanja ili kad osoba radi druge stvari umjesto planiranog učenja (Schowenburg, 2004). Postoji velik broj studenata koji odgađaju obavljanje akademskih obveza, ali ne pokušavaju promijeniti to ponašanje unatoč osjećaju neugode, koji imaju zbog odgađanja. Također nekim studentima takvo ponašanje ne smeta te ne doživljavaju nikakve negativne posljedice (Patrzek, Grunschnel i Fries, 2012).

Izbjegavanje odbojne situacije koja s prolaskom vremena postaje sve više odbojna, predstavlja čest problem kod studentske populacije (Johnson i Perrin, 2016). Rezultati istraživanja pokazuju da između $25 \%$ i $95 \%$ studentske populacije odgađa obavljanje akademskih obveza (Ellis i Knaus, 1977; O’Brien, 2002; Steel, 2007).

Uz akademsku prokrastinaciju, važan čimbenik u području obrazovanja je i izvor kontrole, jer utječe na akademski uspjeh. U psihologiji se izvor kontrole odnosi na stupanj do kojeg ljudi smatraju da imaju kontrolu nad ishodima u njihovim životima, za razliku od vanjskih sila, koje su izvan njihove kontrole. Postoji pozitivna povezanost između akademskog uspjeha i internalnog izvora kontrole (Deniz, Tras i Aydogan, 2009). Naime, studenti koji imaju sklonosti internalnom lokusu kontrole znaju da njihov akademski uspjeh ovisi o njima samima te ulažu više vremena u 
učenje kako bi dosegli svoj cilj. Osobe s internalnim lokusom kontrole će vjerojatnije postići bolji uspjeh u školi, točnije, takvi studenti imaju više samopouzdanja, a osobna učinkovitost proizlazi iz internalnog izvora kontrole (Gujjar i Aijaz, 2014).

Kada se istražuje povezanost sa školskim uspjehom, osobine ličnosti su neizostavni dio prediktorskih varijabli, jer je u nizu istraživanja dokazana njihova povezanost s navedenim kriterijem (Matešić i Zarevski, 2008; Matešić, Ružić i Matešić, 2009). Jedan od najpoznatijih mjernih instrumenata za procjenu osobina ličnosti razvili su Paul T. Costa i Robert R. McCrae, a naziva se NEO-PI-R. Taj inventar ličnosti slijedi petofaktorski model ličnosti, odnosno danas najrelevantniji model za opisivanje ličnosti. Savjesnost je od svih dimenzija ličnosti najkonzistentnija kao prediktor (Matešić i Zarevski, 2008; Matešić, Ružić i Matešić, 2009).

Obrazovanje zauzima važnu ulogu u oblikovanju budućnosti kod pojedinca. Akademski uspjeh može se definirati kao usvajanje specifičnih znanja i vještina koje se provjerava i ocjenjuje na završetku godine. Prema tome, kvaliteta rada kod studenta postaje odraz njegove ocjene na završetku kolegija, odnosno ukupnog postignutog prosjeka. U skladu s tim, ocjene su mjerilo prema kojem studenti zadovoljavaju određeni kriterij (York, Gibson i Ranking, 2015).

S obzirom na to da je akademski uspjeh važan čimbenik u životima studenata, uz visoku pojavnost odgađanja akademskih obveza bilo bi korisno istražiti povezanost navedenih faktora s ostalim čimbenicima kao što su lokus kontrole i osobine ličnosti, koji također utječu na postizanje akademskog uspjeha. Osim toga, relativno rijetka zastupljenost istraživanja ove tematike u Hrvatskoj upućuje na potrebu proširenja znanja u ovom području.

Cilj ovog istraživanja je ispitati odnos akademske prokrastinacije, akademskog lokusa kontrole, osobina ličnosti te akademskog uspjeha kod studenata.

\section{METODA}

\section{Sudionici}

U istraživanju je sudjelovalo 200 sudionika $(N=200)$, pri čemu je $N=151$ sudionika bilo ženskog, a $N=49$ sudionika muškog spola. Najveći dio uzorka je prikupljen na studentima Hrvatskog katoličkog sveučilišta, dok manji dio uzorka čine studenti sa studija Sveučilišta u Zagrebu. Dobni raspon sudionika iznosio je od 19 do 30 godina $(M=21,08, S D=1,91)$.

\section{Mjerni instrumenti}

U istraživanju su korišteni sljedeći mjerni instrumenti: PASS - Skala akademske prokrastinacije (PASS - Procrastination Assessment Scale - Student), Skala aka- 
demskog lokusa kontrole za studente (The Academic Locus of Control Scale for College Students) te NEO petofaktorski inventar (NEO- FFI). Također se od sudionika tražilo da napišu spol, dob, studij koji pohađaju te prosjek ocjena ostvaren u prošlom semestru, zaokružen na dvije decimale. Prosjek ocjena se koristio kao mjera akademskog uspjeha kod studenata.

PASS Skala akademske prokrastinacije (PASS - Procrastination Assesment Scale-Student) je mjerni instrument za akademsku prokrastinaciju. Autori instrumenta su Solomon i Rothblum (1984). Skala se sastoji od dva dijela, u prvom dijelu su pitanja vezana uz šest različitih vrsta akademskih zadataka kao što su pisanje seminara, učenje za ispite, redovito čitanje gradiva. Prvi dio upitnika ima 12 čestica, a sudionici trebaju odgovoriti na sljedeća dva pitanja u svakom od šest različitih područja: „U kojem stupnju odgađate obavljanje zadatka?“ (od 1: Nikad ne odgađam obavljanje ovog zadatka do 5: Uvijek odgađam obavljanje ovog zadatka) te drugo pitanje: "U kojem stupnju odgađanje zadatka predstavlja problem za Vas?" (od 1: Nikad ne predstavlja problem do 5: Uvijek predstavlja problem). Odgovori se procjenjuju na Likertovoj skali od pet stupnjeva, gdje veći rezultat upućuje na veći stupanj prokrastinacije, a mogući dobiveni rezultati su u rasponu od 12 do 60 bodova. Nadalje, u sljedećim akademskim zadacima sudionici su se trebali prisjetiti koliko su skloni odgađanju obveza: pisanje seminara, učenje za ispite, redovito čitanje gradiva tijekom radnog tjedna, obavljanje akademskih administrativnih zadataka, dogovaranje konzultacija sa studentskim savjetnikom ili profesorom te, na kraju, obavljanje akademskih aktivnosti općenito. Bodovi se zbrajaju za oba pitanja vezana uz šest različitih vrsta akademskih zadataka kako bi se dobio ukupan rezultat akademske prokrastinacije za sudionika.

Zatim u drugom dijelu PASS upitnika, koji ne ulazi u ukupan rezultat postignute prokrastinacije, sudionici trebaju procijeniti razloge odlaganja obveza, a tu su istaknute subskale koje mjere strah od neuspjeha i averzivnost prema zadatku. Primjer čestice koja mjeri strah od neuspjeha glasi: "Bili ste zabrinuti da ćete dobiti lošu ocjenu", dok primjer čestice koja mjeri averzivnost studenata prema zadatku glasi: „Imate osjećaj da Vam pisanje seminarskog rada oduzima previše vremena“. Odgovori se procjenjuju na Likertovoj skali od pet stupnjeva gdje veći rezultat upućuje na veći stupanj prokrastinacije. Pouzdanost PASS upitnika izračunat Cronbach-alfa koeficijentom iznosi 0,84 (Onwuegbuzie, 2004, prema Yockey, 2016), dok pouzdanost čitave skale akademske prokrastinacije na uzorku ovog istraživanja iznosi 0,66.

Skala akademskog lokusa kontrole za studente (The Academic Locus of Control Scale for College Students) mjeri lokus kontrole kod studenata. Autor skale je Ashton D. Trice (1985). Skala se sastoji od 28 tvrdnji vezanih uz akademski kontekst. Sudionici su procjenjivali Točno/Netočno čestice kao što su: "Ocjene na studiju su odraz uloženog truda" te "Što ja učim više je određeno studijem i zahtjevima kolegija nego mojim željama". Rezultati u česticama su binarne varijable (0 i 1), a raspon ostvarenih bodova iznosi od 0 do 28 bodova, gdje viši rezultati upućuju na eksternalnu orijentaciju. Pouzdanost ovog upitnika izračunata Cronbach alfa koefi- 
cijentom iznosi 0,70 (Curtis i Trice, 2013), dok pouzdanost čitave skale na uzorku ovog istraživanja iznosi 0,65 .

NEO petofaktorski inventar (NEO-FFI) daje kratku, sveobuhvatnu mjeru pet dimenzija ličnosti, a obuhvaća dimenzije neuroticizma, ekstraverzije, otvorenosti prema iskustvu, ugodnosti i savjesnosti. Autori mjernog instrumenta su Paul T. Costa i Robert R. McCrae. NEO-FFI je skraćena verzija NEO-PI-R inventara ličnosti, kojim se dobiva procjena pet glavnih dimenzija ličnosti u okviru petofaktorskog modela. Svaka od ljestvica namijenjena je jednoj od domena ličnosti, a nema informacija o specifičnim facetama unutar domena. NEO-FFI sastoji se od 60 čestica, a sudionici daju odgovore na Likertovoj skali od pet stupnjeva (od 1: Uopće se ne slažem do 5: U potpunosti se slažem). Primjer čestice u NEO-FFI glasi: Lako se nasmijem. Vrijeme odgovaranja na NEO-FFI nije ograničeno. Rezultat za svaku dimenziju ličnosti dobiva se zbrajanjem rezultata čestica koje pripadaju određenoj dimenziji. Koeficjenti unutarnje pouzdanosti izraženi Cronbach alfa koeficijentima za NEO-FFI ljestvice iznose: neurotizicam $=0,86$, ekstraverzija $=0,77$, otvorenost prema iskustvu $=0,73$, ugodnost $=0,68$, savjesnost $=0,81$ (Costa i McCrae, 2005). Pouzdanost NEO-FFI ljestvica na našem uzorku iznosi: neuroticizam $=0,84$, ekstraverzija $=0,76$, otvorenost prema iskustvu $=0,65$, ugodnost $=0,75$, savjesnost $=0,87$.

Kako bismo odgovorili na prvi problem istraživanja, provedena je multipla regresijska analiza, u kojoj je akademski uspjeh korišten kao kriterijska varijabla, a akademski lokus kontrole, akademska prokrastinacija i osobine ličnosti su prediktorske varijable.

\section{REZULTATI}

Prije provođenja parametrijskih statističkih postupaka potrebno je utvrditi zadovoljavaju li varijable korištene u ovom istraživanju preduvjete za provođenje tih postupaka. Normalnost distribucije rezultata kod varijabli korištenih u statističkim postupcima provjerena je Kolmogorov-Smirnovljevim testom.

Pokazalo se da varijable neuroticizam (K-S =0,200; $p>0,05)$, ekstraverzija $(\mathrm{K}-\mathrm{S}=0,057 ; \mathrm{p}>0,05)$, otvorenost prema iskustvu $(\mathrm{K}-\mathrm{S}=0,050 ; \mathrm{p}>0,05)$ te savjesnost $(\mathrm{K}-\mathrm{S}=0,053 ; \mathrm{p}>0,05)$ ne odstupaju od normalne distribucije. Nasuprot tome, varijable lokus kontrole, prokrastinacija, akademski uspjeh te ugodnost statistički značajno odstupaju od normalne distribucije. Rezultati varijable lokus kontrole upućuju na blago pozitivnu asimetričnu distribuciju (indeks asimetričnosti $\mathrm{S}=0,23$ ) te platikurtičnu distribuciju (indeks spljoštenosti $=-0,43$ ). Također, varijabla prokrastinacija ima blago pozitivnu asimetričnu distribuciju (indeks asimetričnosti $\mathrm{S}=0,26$ ) te leptokurtičnu distribuciju (indeks ispupčenosti $=0,72$ ). $\mathrm{S}$ druge strane, varijabla akademski uspjeh pokazuje negativnu asimetričnu distribuciju (indeks asimetričnosti $\mathrm{S}=-0,51$ ) te leptokurtičnu distribuciju (indeks ispupčenosti 
Tablica 1. Deskriptivni podaci korištenih varijabli

\begin{tabular}{lrcc}
\hline & $M$ & $S D$ & Cronbach alfa \\
\hline Akademski uspjeh & 3,84 & 0,56 & - \\
Neuroticizam & 21,68 & 8,38 & 0,84 \\
Ekstraverzija & 28,41 & 6,60 & 0,76 \\
Otvorenost prema iskustvu & 26,73 & 6,26 & 0,65 \\
Ugodnost & 30,26 & 6,44 & 0,75 \\
Savjesnost & 31,49 & 7,59 & 0,87 \\
Akademska prokrastinacija & 31,98 & 6,84 & 0,65 \\
Akademski lokus kontrole & 12,10 & 3,90 & 0,65 \\
\hline
\end{tabular}

$=1,55$ ). Varijabla ugodnost upućuje na negativnu asimetričnu distribuciju (indeks simetričnosti $S=-0,82$ ) te leptokurtičnu distribuciju (indeks ispupčenosti $=1,41$ ). Provjeravanjem Q-Q dijagrama te izračunom $z$-vrijednosti indeksa asimetričnosti $i$ spljoštenosti dokazano je da su odstupanja od normalne distribucije prihvatljiva te da neće narušiti točnost rezultata.

Nakon procjene o zadovoljenju preduvjeta za provedbu statističkih postupaka, s ciljem odgovaranja na probleme ovog istraživanja provedene su korelacijske i regresijske analize.

U Tablici 1. navedeni su deskriptivni podaci o svim varijablama korištenim u ovom istraživanju.

Provedena je multipla regresijska analiza, u kojoj je akademski uspjeh korišten kao kriterijska varijabla, a akademski lokus kontrole, akademska prokrastinacija i osobine ličnosti su prediktorske varijable. Navedeni prediktori služe za provjeru doprinosa postignutog akademskog uspjeha, odnosno kriterija u statističkoj analizi.

Prije provođenja regresijske analize potrebno je provjeriti zadovoljavaju li varijable preduvjete za provođenje statističkog postupka. Osim prethodno navedenih postupaka kojima se vršila provjera zadovoljavanja kriterija za daljnju provedbu statističkih postupaka, dodatno se provela analiza reziduala na varijablama koje ulaze u regresijsku analizu. Ustanovljeno je da varijable zadovoljavaju kriterije za uvrštavanje u regresijsku analizu.

Kako bi se utvrdila povezanost između varijabli uključenih u istraživanje, provela se korelacijska analiza. U Tablici 2. navedeni su rezultati interkorelacije između prediktorskih varijabli i kriterija. Rezultati su pokazali značajnu negativnu korelaciju akademskog uspjeha i akademske prokrastinacije $(r=-0,203, p<0,01)$. Također je dobivena značajna negativna korelacija akademskog uspjeha i akademskog lokusa kontrole $(r=-0,331, p<0,01)$. Dobiveni rezultati su pokazali pozitivnu korelaciju akademskog uspjeha i savjesnosti kao osobine ličnosti $(r=0,391$, $p<0,01)$. Ostale prediktorske varijable nisu ostvarile značajnu povezanost $\mathrm{s}$ kriterijem. 


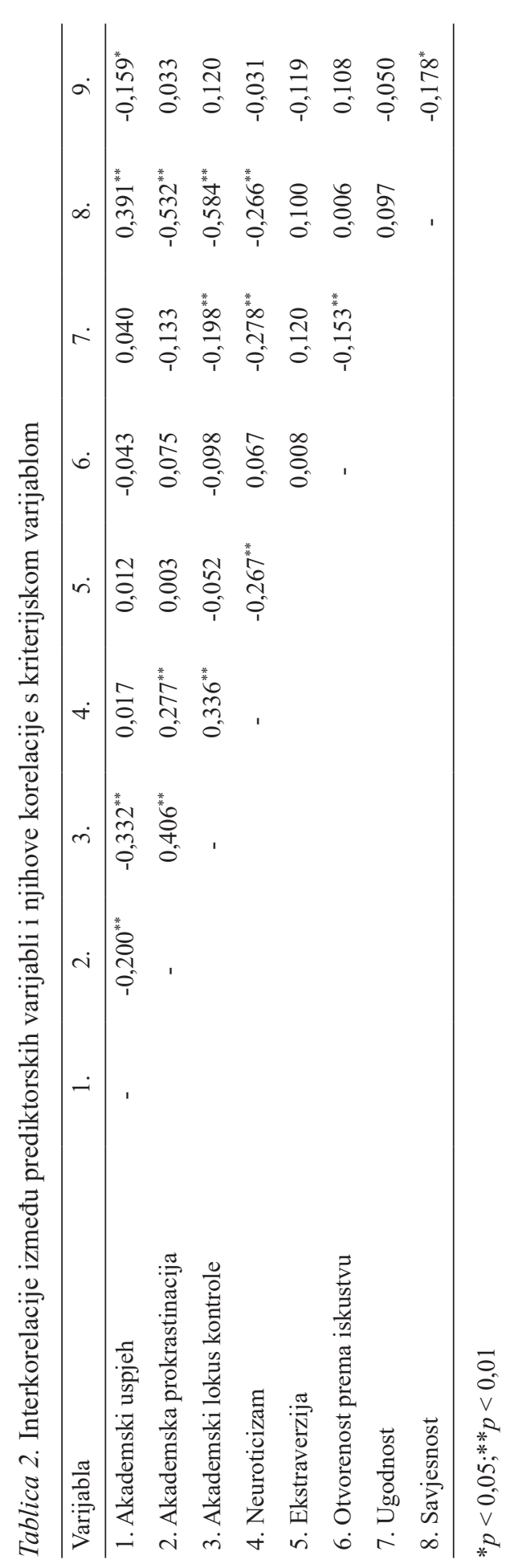

(C) "Naklada Slap", 2019. Sva prava pridržana. 
Dobivene korelacije prediktora s kriterijem su niske do umjerene, prema tome su varijable prikladne za provedbu regresijske analize. Također, pokazano je da među varijablama ne postoji multikolinearnost, a vrijednosti VIF $i$ Tolerance dobivene su unutar dopuštenih granica $(V I F<10$, Tolerance $>0,1)$.

Kako bismo odgovorili na problem ovog istraživanja, provedena je multipla regresijska analiza. U statističku analizu istovremeno ulaze prediktori akademski lokus kontrole, akademska prokrastinacija i osobine ličnosti $(F=6,18, d f=8,191$, $p<0,01)$, te se model pokazao statistički značajnim.

Rezultati provedene analize u Tablici 3. pokazuju da se opisanim prediktorskim varijablama može objasniti ukupno $20,1 \%$ ukupne varijance akademskog uspjeha kod studenata $\left(R^{2}=0,201\right)$. Akademski lokus kontrole $(\beta=-0,212, p<0,05)$, neuroticizam $(\beta=0,165, p<0,05)$ te savjesnost $(\beta=0,307, p<0,05)$ značajno objašnjavaju akademski uspjeh kod studenata.

Kako bi se utvrdila povezanost između osobina ličnosti i akademske prokrastinacije kod studenata, upotrijebljen je Pearsonov koeficijent korelacije, koji možemo iščitati u Tablici 2. s interkorelacijama svih varijabli.

Utvrđena je značajna povezanost između akademske prokrastinacije i neuroticizma kod studenata $(r=0,277, p<0,01)$. U skladu sa značajnom pozitivnom povezanošću, rezultati pokazuju da su studenti koji imaju izraženiji neuroticizam kao osobinu ličnosti skloniji akademskoj prokrastinaciji. Također, pronađena je značajna povezanost između akademske prokrastinacije i savjesnosti kod studenata $(r=-0,532, p<0,01)$. Negativan smjer povezanosti pokazuje da su studenti s većim stupnjem savjesnosti manje skloni odgađanju akademskih obveza.

Tablica 3. Rezultati multiple regresijske analize s akademskim uspjehom kao kriterijskom varijablom $(N=200)$

\begin{tabular}{lccc}
\hline Prediktori & $\mathrm{B}$ & $R$ & $s r$ \\
\hline Akademska prokrastinacija & 0,012 & 0,011 & 0,010 \\
Akademski lokus kontrole & $-0,212^{*}$ & $-0,179^{*}$ & $-0,162^{*}$ \\
Neuroticizam & $0,165^{*}$ & $0,159^{*}$ & 0,143 \\
Ekstraverzija & $-0,018$ & $-0,019$ & $-0,017$ \\
Otvorenost prema iskustvu & $-0,070$ & $-0,075$ & $-0,067$ \\
Ugodnost & 0,004 & 0,004 & 0,004 \\
Savjesnost & $0,307^{*}$ & $0,245^{*}$ & $0,225^{*}$ \\
\hline & $R^{2}$ & 0,201 & \\
\cline { 2 - 4 } & $F$ & $6,18^{* *}$ & $(d f=8,191)$ \\
\hline
\end{tabular}

Napomena: $s r$-semi parcijalna korelacija ${ }^{*} p<0,05,{ }^{* *} p<0,01$ 
Između mjera ekstraverzije $(r=0,003, p>0,05)$, otvorenosti prema iskustvu $(r=0,075, p>0,05)$ i ugodnosti $(r=-0,133, p>0,05)$ i akademske prokrastinacije ne postoji značajna povezanost.

\section{RASPRAVA}

Opći cilj provedenog istraživanja bio je ispitivanje odnosa akademske prokrastinacije, akademskog lokusa kontrole, osobina ličnosti te akademskog uspjeha kod studenata.

Rezultati provedenog istraživanja pokazuju da je veći stupanj odgađanja akademskih obveza povezan s lošijim akademskim uspjehom, odnosno studenti koji manje odgađaju akademske obveze postižu bolji uspjeh. Prokrastinacija najčešće smanjuje radni učinak studenata što donosi lošije rezultate. Akademska prokrastinacija ima negativne posljedice kao što su varanje na ispitima te loš akademski uspjeh, koji se izražava kroz lošiji prosjek ocjena (Kim i Seo, 2015). Razumijevanje i osvještavanje odgađanja akademskih obveza kod studenata olakšava prevenciju takvog ponašanja u akademskom okruženju. Jedno od mogućih objašnjenja ovih rezultata može biti utrka s vremenom, koja je svojstvena pojava kod prokrastinacije. Takav način odgađanja uzrokuje neprospavane noći, visoku razinu stresa i osjećaja nezadovoljstva zbog nedostatka vremena za obavljanje obveza. Naime, vremenski pritisak koji se pojavljuje zbog odgađanja obveza smanjuje točnost i redovitost te tako negativno utječe na akademsku izvedbu (Van Eerde, 2003). Za studente nije neobično da sami tvrde da trebaju prestati s odgađanjem obveza. Zbog negativnih posljedica odgađanja većina studenata želi smanjiti akademsku prokrastinaciju (Grunschel, Patrzek, Klingsieck i Fries 2018).

U obrazovnoj domeni, internalni je lokus kontrole pozitivan prediktor akademskog uspjeha, a eksternalni lokus kontrole je negativan prediktor akademskog uspjeha (Deniz i sur., 2009; Gujjar i Aijaz 2014).

Rezultati istraživanja su pokazali da je savjesnost pozitivan prediktor akademskog uspjeha, no dobiveni rezultati pokazuju da je neuroticizam također pozitivan prediktor akademskog uspjeha. Od svih osobina ličnosti, savjesnost je najpoželjnija što se tiče uspjeha tijekom obrazovanja. Savjesni ljudi se opisuju kao visoko odgovorne osobe sklone postignuću. Takve osobine ih potiču na postizanje boljeg akademskog uspjeha. Prema tome nije ni začuđujuće da savjesnost ima velik doprinos u predviđanju akademskog uspjeha (Chamorro-Premuzic i Furnham, 2003; Lounsbury, Sundstrum, Gibson i Loveland, 2003; Bratko, Chamoro i Saks, 2006; Matešić, ml. i Zarevski, 2008). Savjesnost se često pozitivno povezuje s akademskim uspjehom, a taj faktor se odnosi na ulaganje truda za ostvarivanje ciljeva što doprinosi boljoj koncentraciji i učenju, što u konačnici doprinosi boljem akademskom uspjehu (Poropat, 2009). Studenti koji postižu visoke rezultate na dimenziji savjesnosti su pouzdani i orijentirani na ciljeve koje žele postići. 
Moguće objašnjenje dobivenog rezultata prediktivne vrijednosti neuroticizma na akademski uspjeh može biti da studenti koji su visoko motivirani za ostvarenje dobrog uspjeha mogu osjetiti neku razinu anksioznosti povezane s uspjehom, koja će ih dodatno motivirati prema učenju i boljem savladavanju gradiva (Komarraju, Karau i Schmeck, 2009). Osim toga, postojanje određene razine anksioznosti i perfekcionizma kod studenata s izraženim neuroticizmom potiče veću razinu spremnosti na izvedbu akademskih zadataka kod studenata (Bratko i sur., 2006).

Neplanirano odgađanje zadataka može se smatrati navikom, dok se kronično odgađanje zadataka interpretira više kao osobina ličnosti (Hoppe, Prokop i Rau, 2018). Što se tiče povezanosti s osobinama ličnosti, prokrastinacija se najčešće povezuje s neuroticizmom i savjesnošću (Milgram i Tenne, 2000).

$\mathrm{U}$ istraživanju je dobivena pozitivna povezanost između akademske prokrastinacije i neuroticizma kao dimenzije ličnosti kod studenata. Prema dosadašnjim istraživanjima neuroticizam je pozitivno povezan s prokrastinacijom (Milgram, Batori i Mowrer, 1993; Johnson i Bloom, 1995; Schouwenburg i Lay, 1995; Watson, 2001; Lee, Kelly i Edwards, 2006). Neuroticizam se definira kao sklonost doživljavanju negativnih emocija i neugode kroz osjećaj straha, depresije i smanjenog samopouzdanja (Costa i McCrae, 1992).

Nadalje, nije ostvarena značajna pozitivna povezanost između akademske prokrastinacije i ekstraverzije. Istraživanja pokazuju da ekstraverti zbog svoje želje za više socijalnih stimulacija, odnosno izraženije potrebe za društvenosti, mogu imati više distrakcija tijekom obavljanja akademskih zadataka (Ferrari, 1995; Steel, 2007).

Kao što je već istaknuto, ekstraverzija se odnosi na sklonost pojedinca pristupanju društvenim situacijama. Jedno od mogućih objašnjenja dobivenog rezultata u ovom istraživanju može biti da su ekstraverti aktivni i asertivni pojedinci koji su skloni uključivanju u više aktivnosti u kratkom vremenu, ali istovremeno preuzimaju odgovornost nad situacijom. Sklonost takvom ponašanju povezana je s aktivnom prokrastinacijom (Kim, Fernandez i Terrier, 2017). Naveden sklop ponašanja karakterizira odgađanje sa svrhom da se poveća učinkovitost.

Također nije dobivena značajna negativna povezanost akademske prokrastinacije i ugodnosti. Nadalje, u ovom istraživanju je potvrđena negativna povezanost savjesnosti s prokrastinacijom (Costa i McCrae, 1992; Johnson i Bloom, 1995; Schouwenburg i Lay, 1995; Lay i sur., 1998; Lee i sur., 2006). Savjesne osobe sklone su organiziranom ponašanju i upornosti prema ostvarivanju ciljeva (Costa i McCrae, 2005). Osim toga, ponašaju se prema pravilima te su marljive i točne $u$ izvršavanju obveza. Takvim ponašanjem pojedinci s izraženom savjesnošću postižu bolje rezultate tijekom školovanja te kasnije na radnom mjestu (Larsen i Buss, 2008). Prema ovim spoznajama može se reći da je savjesnost poželjna osobina u različitim životnim domenama.

Varijabla otvorenost prema iskustvu nije značajno povezana s akademskom prokrastinacijom. Ni u prijašnjim istraživanjima nije ostvarena značajna povezanost 
otvorenosti prema iskustvu s akademskom prokrastinacijom (Watson, 2001; Steel, 2007).

\section{ZAKLJUČAK}

Akademski uspjeh je važna odrednica uspješnosti studenata u njihovu budućem radu. Zbog toga je važno usmjeriti pažnju na čimbenike koji doprinose razvoju akademskog uspjeha.

Ispitivanjem razine akademske prokrastinacije uspješnije bi se identificirala skupina studenata koji imaju sklonost odgađanju obveza te bi se njihove sklonosti odgađanju mogle umanjiti kroz educiranje o učinkovitom učenju, postavljanju ciljeva i vremenskih rokova. Jedan način uspješnog smanjenja akademske prokrastinacije je davanje manje opsežnih zadataka studentima u kraćim vremenskim razdobljima (Johnson, Perrin, Salo, Deschaine i Johnson, 2016). Na taj način bi studenti mogli umanjiti odgađanje akademskih obveza te povećati vjerojatnost uspjeha na studiju. Upravo se na samoregulaciji temelji postupak smanjenja akademske prokrastinacije (Grunschel i sur., 2018).

Jedno od najvećih ograničenja istraživanja je uzorak sudionika. Naime, većinu sudionika u ovom istraživanju činili su studenti s Hrvatskog katoličkog sveučilišta. Osim toga, većinu uzorka ovog istraživanja činile su studentice, dok je studenata bilo u manjem broju pa je zbog metodoloških razloga preporučljivo u budućim istraživanjima smanjiti brojčanu razliku između spolova (Milas, 2005). Nadalje, postignuti rezultati na osobinama ličnosti i akademskoj prokrastinaciji odraz su mjere samoprocjene, a bilo bi poželjno dobiti rezultate i na ponašajnoj razini. Osim toga, mjere prokrastinacije i prosjek ocjena uzete su istovremeno, a za prediktivne svrhe moglo bi biti bolje kada bi se sklonost prokrastinaciji mjerila prije postignutog prosjeka ocjena (Terrier, Kim i Fernandez, 2016).

Konačno, kroz empirijski utemeljene spoznaje različitih istraživanja u svijetu i Hrvatskoj uočava se visoka prevalencija studentske populacije koja je sklona akademskoj prokrastinaciji unatoč postizanju lošijih rezultata. S obzirom na sve rečeno, poželjno bi bilo odmah započeti borbu protiv odgađanja, a ne ostaviti je za sutra.

\section{LITERATURA}

Bratko, D., Chamoro, T. i Saks, Z. (2006). Personality and school performance: Incremental validity of self and peer-ratings over intelligence. Personality and Individual Differences, 41, 131-142. http://dx.doi.org/10.1016/j.paid.2005.12.015

Chamorro-Premuzic, T. i Furnham, A. (2003), Personality Traits and Academic Examination Performance. European Journal of Personality, 17, 237-250. https://doi.org/10.1002/ per.473 
Costa, P. T. i McCrae, R. R. (1992). Normal personality assessment in clinical practice: The NEO Personality Inventory. Psychological Assessment, 4, 5-13.http://dx.doi. org/10.1037/1040-3590.4.1.5

Costa, P. T., Jr. i McCrae, R. R. (2005). NEO-PI-R Priručnik. Jastrebarsko: Naklada Slap.

Curtis, N. A. i Trice, A. D. (2013). A revision of the academic locus of control scale for college students. Perceptual and Motor Skills, 116, 817-829.

Deniz, M., Tras, Z. i Aydogan, D. (2009). An Investigation of Academic Procrastination, Locus of Control, and Emotional Intelligence. Educational Sciences: Theory and Practice, 9(2), 623-632. Dostupno na: https://eric.ed.gov/?id=EJ847770

Ellis, A. i Knaus, W. J. (1977). Overcoming procrastination. New York: Signet Books.

Ferrari, J. R. (1992). Psychometric validation of two Procrastination inventories for adults: Arousal and avoidance measures. Journal of Psychopathology and Behavioral Assessment, 14, 97-110.

Gendron, A. L. (2011). Active procrastination, self-regulated learning and academic achievement in university undergraduates. Neobjavljena doktorska disertacija. University of Victoria.

Grunschel, C., Patrzek, J., Klingsieck, K. B. i Fries, S. (2018). "I'll stop procrastinating now!" Fostering specific processes of self-regulated learning to reduce academic procrastination. Journal of Prevention \& Intervention in the Community, 46, 143-157. 10.1080/10852352.2016.1198166

Gujjar, A. A. i Aijaz, R. (2014). A study to investigate the relationship between locus of control and academic achievement of students. i-Manager's Journal on Educational Psychology, 8, 1-9. http://dx.doi.org/10.26634/jpsy.8.1.2763

Hoppe, J. D., Prokop, P. i Rau, R. (2018). Empower, not impose! - Preventing academic procrastination. Journal of Prevention \& Intervention in the Community, 46(2), 184-198

Johnson, J. i Bloom A. (1995). An analysis of the contribution of the five factors of personality to variance in academic procrastination. Personality and Individual Differences, $18,127-133$.

Johnson, P. E., Perrin, C. J., Salo, A., Deschaine, E., i Johnson, B. (2016). Use of an explici t rule decreases procrastination in university students. Journal of Applied Behavior analysis, 49, 346-358. http://dx.doi.org/10.1002/jaba.287A

Kim, K., R. i Seo, E., H. (2015). The relationship between procrastination and academic performance: A meta-analysis. Personality and Individual Differences, 82, 26-33.

Kim, S., Fernandez, S. i Terrier, L. (2017). Procrastination, personality traits, and academic performance: When active and passive procrastination tell a different story. Personality and Individual Differences, 108, 154-157.

Komarraju, M., Karau, S. J. i Schmeck, R. R. (2009). Role of the big five personality traits in predicting college students' academic motivation and achievement. Learning and Individual Differences, 19, 47-52. http://dx.doi.org/10.1016/j.lindif.2008.07.001

Larsen, R. J. i Buss, D. M. (2008). Psihologija ličnosti. Jastrebarsko: Naklada Slap.

Lay, C., Kovacs, A. i Danto, D. (1998). The relation of trait procrastination to the big-five factor conscientiousness: an assessment with primary-junior school children based on self-report scales. Personality and Individual Differences, 25(2), 187-193. 
Lee, D. G., Kelly, K. R. i Edwards, J. K. (2006). A closer look at the relationships among trait procrastination, neuroticism, and conscientiousness. Personality and Individual Differences, 40, 27-37. http://dx.doi.org/10.1016/j.paid.2005.05.010

Lounsbury, J. W., Sundstrum, E., Gibson, L. W. i Loveland, J. L. (2003). Broad versus narrow personality traits in predicting academic performance of adolescents. Learning and Individual Differences, 14, 65-75.

Matešić, K. ml., Zarevski, P. (2008). Povezanost opće inteligencije i dimenzija ličnosti sa školskim postignućem. Metodika: časopis za teoriju i praksu metodika u predškolskom odgoju, školskoj $i$ visokoškolskoj izobrazbi, 9, 260-270. Dostupno na https://hrcak.srce. $\mathrm{hr} / 34784$

Matešić, K., Ružić, V. i Matešić, K. (2009). Relationship between personality factors measured by the BFQ and school success of high school students. Odgojne znanosti, 11(17), 171-181.

Milas, G. (2005). Metodologija istraživanja u psihologiji i drugim društvenim znanostima. Jastrebarsko: Naklada Slap.

Milgram, N. i Tenne, R.(2000). Personality correlates of decisional and task avoidant procrastination. European Journal of Personality, 14, 141-156.

Milgram, N., A., Batori, G. i Mowrer, D. (1993). Correlates of academic procrastination. Journal of School Psychology, 31, 487-500. http://dx.doi.org/10.1016/00224405(93)90033-F

O'Brien, W. K. (2002). Applying the transtheoretical model to academic procrastination. Neobjavljena doktorska disertacija. University of Houston.

Onwuegbuzie, A. J. (2004). Academic procrastination and statistics anxiety. Assessment and Evaluation in Higher Education, 29, 3-19.

Patrzek, J., Grunschel, C. i Fries, S. (2012). Academic procrastination: The perspective of university counsellors. International Journal for the Advancement of Counselling, 34, 185-201. http://dx.doi.org/10.1007/s10447-012-9150-z

Poropat, A. E. (2009). A meta-analysis of the five-factor model of personality and academic performance. Psychological Bulletin, 135, 322-338. http://dx.doi.org/10.1037/ a0014996

Schouwenburg, H. C. (2004). Procrastination in Academic Settings: General Introduction. 3-17. http://dx.doi.org/10.1037/10808-001

Schouwenburg, H., C. i Lay, C., H. (1995). Trait procrastination and the big-five factors of personality. Personality and Individual Differences, 18, 481-490. http://dx.doi. org/10.1016/0191-8869(94)00176-S

Solomon, L. J. i Rothblum, E. D. (1984). Academic procrastination: Frequency and cognitive-behavioral correlates. Journal of Counseling Psychology, 31, 503-509. http://dx.doi. org/10.1037/0022-0167.31.4.503

Steel, P. (2007). The nature of procrastination: A meta-analytic and theoretical review of quintessential self-regulatory failure. Psychological Bulletin, 133, 65-94. http://dx.doi. org/10.1037/0033-2909.133.1.65

Terrier, L., Kim, S. i Fernandez, S. (2016). Who are the good organizational citizens for the environment? An examination of the predictive validity of personality traits. Journal of Environmental Psychology, 48, 185-190. 
Trice, A. D. (1985). An academic locus of control scale for college students. Perceptual and Motor Skills, 61(31), 1043-1046. https://doi.org/10.2466/pms.1985.61.3f.1043

Van Eerde, W. (2000). Procrastination: Self-regulation in initiating aversive goals. Applied Psychology, 3, 372-389. http://dx.doi.org/10.1111/1464-0597.00021

Watson, D., C. (2001). Procrastination and the five-factor model: A facet level analysis. Personality and Individual Differences, 30, 149-158. http://dx.doi.org/10.1016/S01918869(00)00019-2

York, T. T., Gibson, C. i Rankin, S. (2015). Defining and Measuring Academic Success. Practical Assessment, Research \& Evaluation, 20, 5-7. Dostupno na: https://www.researchgate.net/publication/278305241_Defining_and_Measuring_Academic_Success

Živčić-Bećirević, I., Smojver-Ažić, S., i Martinac Dorčić, T. (2015). Odrednice odugovlačenja u akademskom kontekstu. Društvena istraživanja: časopis za opća društvena pitanja, 24, 47-67. https://doi.org/10.5559/di.24.1.03

\title{
RELATIONSHIP BETWEEN ACADEMIC PROCRASTINATION, ACADEMIC LOCUS OF CONTROL, PERSONALITY TRAITS AND ACADEMIC SUCCESS
}

\begin{abstract}
The aim of this research was to examine the relationship between academic procrastination, academic locus of control, personality traits and academic success. The relationship between academic procrastination and personality traits was also examined.

Variables used in this research explained $20.1 \%$ of the variance of academic success. Academic procrastination is not a significant predictor for explaining academic achievement. The results also show that a higher degree of academic procrastination is connected with lower grades, and vice versa. Significant predictors of academic success are conscientiousness and neuroticism. This research showed that academic procrastination is connected with high results on neuroticism, and low results on conscientiousness. Internal locus of control is a significant predictor of academic success, which explains that students with internal locus of control have better academic success than students with external locus of control.
\end{abstract}

Key words: academic procrastination, academic success, personality traits, academic locus of control

Primljeno: 13. 05. 2019. 